\title{
Research on the Optimization of Listed Companies' Legal Responsibility in Financial Statement Fraud
}

\author{
Hangmin Li \\ Guanghua Law School \\ Zhejiang University \\ Hangzhou, China \\ Lihangmin0325@gmail.com
}

\begin{abstract}
The Securities Law of the People's Republic of China sets the relevant tort liability and administrative liability for the financial statement fraud in listed companies, the purpose of which is to ensure the investors' legal rights and interests and punish the illegal information disclosure of listed companies. However, the implementation of the current financial statement fraud accountability system still has certain problems, which results in the undesired effect that civil liability and administrative punishment system has on the financial performance of listed companies to regulate the effectiveness of fraud. Compared to the foreign legislative experience on the listed companies' responsibility in the financial statement fraud, it is suggested that the public interest litigation system should be introduced into the litigation of civil liability for securities infringement, and the scope of the responsibility and the amount of penalty should be adjusted so as to achieve the purpose of reconstructing the financial statement fraud responsibility system of listed companies and consolidating the order of securities market.
\end{abstract}

Keywords-listed companies; financial statement fraud; civil tort liability; administrative punishment

\section{INTRODUCTION}

In recent years, the financial statement fraud cases of listed companies are constantly appearing, and the behaviors of financial statement fraud of listed companies is reflected in the securities market including many aspects such as fraudulent issuance, insider trading and false statements in continuous information disclosure. Among them, Wanfu Biotechnology Agricultural Development Co., Ltd., Yunnan Greenland Biological Technology Co., Ltd. and so on were punished by the CSRC in 2013 because of going public with huge financial statement fraud, which aroused widespread concerns, and the disclosure of Nanjing Textiles Import \& Export Co., Ltd.'s financial statement fraud in the first half of 2014 is a typical false statement of financial report in sustained information disclosure. The legal issues involved in the financial statement fraud of listed companies are becoming more and more complicated. The focus of the controversy includes the internal control and auditing mechanism of China's listed companies, the formulation of accounting standards, securities infringement civil action mechanism], and the discussion on the liability of securities administrative punishment [1]-[2].
In the Nanjing Textiles case, the administrative penalty decision from China's Securities Regulatory Commission identified the cumulative fictitious profit of 344 million of the Nanjing Textiles from 2006 to 2010. The percentage of fictitious profits ranging from $130 \%$ to $5500 \%$ in the exposure of Nanjing Textiles case in 2014. ${ }^{(1)}$ Nanjing Textiles case had a very bad impact on the confidence of the securities investors and caused a huge blow in the securities market. The greater controversy of Nanjing Textiles case is that the investors question the CSRC's decision on the issuance of administrative penalties, which includes a fine of only 500,000 yuan on the company, the company executives and the relevant responsible personnel together a fine of 1.53 million yuan of administrative penalty. This decision has been questioned that the cost of fraud and fraud proceeds are not quite the same and illegal costs are too small, which will encourage the financial statement fraud of listed companies.

As a securities regulatory body authorized by the Securities Law of the People's Republic of China (CSRC), the CSRC has been given administrative functions of centralized supervision and management of the national securities market. In order to ensure the smooth implementation of the function, the CSRC set up administrative responsibility on the illegal acts in accordance with the relevant legal liabilities so as to play a disciplinary and deterrent role to the illegal. The dispute of Nanjing Textiles case reflects a problem: whether China's administrative punishment of financial statement fraud on the listed companies is reasonable and whether there is space for improvement? At the same time, the present situation that investors place great expectations on the punishment decision of the administrative supervision institution reflects the shortcomings of the private law remedies in China's securities trading market because the civil actions of securities infringement has always been difficult to accept, difficult for trial, hard to obtain compensate, which has caused a great blow to the enthusiasm of investors who take private law remedies to protect their rights and interests in the financial statement fraud of listed companies.

It should be noted that the financial statement fraud of listed companies can be reflected in the securities issuance, listing, securities trading and other links, and this paper

(1) The data comes from the Administrative Penalty Decision ([2014] 42) from China's Securities Regulatory Commission. 
discusses the financial statement fraud behavior of listed companies, which is limited to continuous information disclosure stage of the financial statement fraud, reflecting in the interim report, mid-term report and the annual report of the financial accounting report and false statements of the financial events which has a significant impact on the company.

\section{THE BASIC FRAMEWORK OF LEGAL LIABILITY FOR LISTED COMPANIES' FINANCIAL STATEMENT FRAUD}

\section{A. Establishment of Legal Liability for Financial statement fraud of Listed Companies}

The authenticity, transparency and completeness of financial reports published by listed companies are the important basis for investors to judge market risks and make investment decisions. Effective financial reporting system of listed companies is of great significance to improve the efficiency of capital market resource allocation [3]. The quality of financial reports of listed companies can be improved through the strict supervision of financial reports of listed companies. In addition, the false statements caused by financial statement fraud can be restricted to a certain extent, the trading behavior of securities market can be regulated and the legitimate rights and interests of investors can be guaranteed. In a speech at a time after the outbreak of financial statement fraud scandals by listed companies like Enron and WorldCom, the chairman of the Securities and Exchange Commission (SEC), emphasized that audited financial reporting is the basis of a securities market transaction, and accurate financial information helps the market to discover the true value of trading securities, which in turn will improve the quality of trading in the securities market [4].

In the establishment of legal liability system of corporate financial statement fraud in China, it can be said that the Company Law and the Accounting Law are based on regulating the organization and behavior of the company, so as to protect the interests of the company, creditors and shareholders, and ensure the authenticity and integrity of the company's accounting information to standardize accounting behavior. ${ }^{(2)}$ Therefore, set up a general legal responsibility for the broad sense of the company's financial statement fraud. In practice, for the sake of shareholders, investors and market confidence, it does not often occur in the listed companies in order to evade taxes and conceal the profits of financial statement fraud. The financial statement fraud of listed companies mainly take the form of the inflated assets, profits, transactions and thus create a favorable market information in order to improve the confidence of investors for their future earnings, encourage investment and raise the price for the purpose of its financial statement fraud. The majority of securities investors make investment judgment based on false financial information and thus become the direct victim groups of financial statement fraud of listed company. The special motive, object of victim and scope of influence of listed companies' financial statement fraud determines that the law of the Company Law and the Accounting Law are limited by their own legislative purposes and scope of regulation. However,

\footnotetext{
(2) Refer to Article 202 of the Company Law of the People's Republic of China, Article 43 of the Accounting Law of the People's Republic of China.
}

faced with the financial statement fraud of listed companies, this particular subject, the huge loss of the stock market and investors is still beyond the reach though listed companies should count on legal liability for financial statement fraud. Therefore, there are appropriate civil, administrative, and even criminal liability for the financial statement fraud of listed companies, special subject, in the Securities Law and Criminal Law. ${ }^{(3)}$ And from the horizontal and vertical comparison of the amount of administrative fines and legal liability categories, it can be considered that China's laws impose more stringent than the general legal liability on the financial statement fraud of listed companies.

\section{B. Civil and Administrative Responsibility of Listed Companies' Financial statement fraud in Securities Law}

In the accountability of financial statement fraud of listed companies, the decision of administrative penalty made by CSRC and the basis of litigation of civil compensation for securities infringement by the impaired investor come from the provisions of China Securities Law. In Article 69 of the Securities Law and the provisions of Article 193, respectively, set the provisions of the securities tort liability and the composition of the elements of the responsibility of securities and the way of responsibility.

\section{1) Civil Liability}

In accordance with the relevant provisions of Article 69 of the Securities Law, the listed companies shall bear the losses caused by the financial counterfeiting of the listed companies which made investors suffer losses in securities trading in the annual report, mid-term report and interim report document of their companies. Directors, supervisors and other persons directly responsible for the listed company shall be jointly and severally liable, and the controlling shareholder and the actual controller shall bear the fault liability. The tort liability is set mainly for the purpose of remedying the loss of the investors who suffer from the false information and non-market risk of the securities transaction. The Supreme Court in 2003 made a specific explanation to the application of a number of provisions of civil compensation cases on the trial caused by false statements in the securities market in judicial trial. It is noteworthy that investors did not suffer the actual loss before the disclosure, and they only be offended by the right to know its true financial condition and potential investment loss risks caused by the information disclosure. After the disclosure of information, the real business situation of listed companies is disclosed by the market, credit levels declining and causing stock prices fell. At this time, the financial losses investors suffer caused by listed companies were able to show. It also shows that the civil liability system in China's securities market is a remedy for the risk of market, besides the artificial fluctuation of the stock market and the risk of investment, which is caused by the man-made reason of the tort of the false statement caused by the false financial statements in judicial interpretation.

\footnotetext{
${ }^{8}$ Refer to Article 69 of the Securities Law of the People's Republic of China, Article 193 and Article 161 of the Criminal Law of the People's Republic of China.
} 


\section{2) Administrative Punishment}

In Chapter 11 of "Securities Law", the legal responsibility embodied in the provisions of this law fully shows the "responsibility of this Law" as an administrative supervision [5]. The financial liability of the listed company also includes the listed company, the directly responsible person in charge, the other responsible persons and the controlling shareholder as well as the actual controller of the listed company. In the view of securities regulation around the world, the behavior of imposing administrative penalty on the illegal act of the listed company comes from the Insider Dealing Punishment Act issued by the United States in 1984. However, the administrative fines for the financial statement fraud of listed companies was only reflected in the Securities Supplementary and Stock Reform Act of 1990, which gives the US securities regulatory authorities the power to impose administrative penalties on the wrongful acts in the judicial and administrative supervision [6]. Under the securities law system, the financial penalties of listed companies and related personnel can be used to prevent the offender from gaining profits from the illegal acts. On the other hand, it can increase the illegal cost of the securities law, which can hinder the illegal behavior.

\section{REFLECTION ON THE VALIDITY OF THE CURRENT LEGAL RESPONSIBILITY IN SECURITIES LAW}

\section{A. The Litigation Rights of Securities Investors and Its Current Situation}

A securities investor who has been infringed by a false statement due to fraudulent financial statements of listed companies has been given the right of action in Article 69 of the Securities Law of the People's Republic of China on the civil liability for securities infringement. In 2003, the People's Supreme Court on the Trial of Provisions of Civil Compensation Cases Caused by False Statements in the Securities Market also provides acceptance, jurisdiction, litigation, illegal behavior and rules of such civil compensation cases as well as the reasons for exemption, joint tort liability and loss identification. According to the above-mentioned laws and judicial interpretations, securities investors who suffered losses due to financial statement fraud of listed companies have the right to sue for compensation. But in reality, it is still a rough road for investors to claim the listed companies with financial statement fraud by using the securities law enforcement, in addition to the lack of effective mass litigation system, long time for litigation, high cost of litigation.

In recent years, we can find the directors, supervisors, senior management and the controlling shareholder and the actual controller bear the responsibility of fault in addition to listed companies in the civil compensation litigation the court received which caused by financial statement fraud of the listed companies. However, almost all the defendants in the civil litigation compensation cases against listed companies' misrepresentation do not have the above-mentioned main body, often only the listed company being the defendant. In addition to the scope of the defendant which is limited in the actual case, investors sue the false statements of listed companies on the grounds of financial statement fraud and request for civil compensation. In addition, the request will be dismissed for the reason that financial statement fraud of listed companies is too low, or the fraud is not a major event and will cause little impact on the securities market, resulting in misuse and waste of judicial resources. As the appellate court in the Wang Minhua and other 18 securities investors v Huawen Media Investment Group Co., Ltd. said: "whether the matter and the data on the financial accounting report constitute a major event, the comprehensive judgments should be made from the amount involved, the nature of the incident and the impact. In the 2008 annual report, Huawen company adjusted the relevant data in accordance with the 'inspection conclusions and treatment decisions', in addition to attributable to the parent company's net profit (increase $13.18 \%$ ) and the total profit (5.16\%), and the rest of the subjects are very small and cannot have a real impact on the stock market so the disclosed information does not constitute a misstatement. ${ }^{(4)}$

\section{B. Reason Analysis: Conflict between Judicial Interpretation and Case in Practice}

According to the court judgment in Huawen Media case, the reason why the investors of Huawen Media cannot prevail in the litigation of false statement of civil liability of the listed company is that the court has differences in the practical understanding and judicial interpretation of misrepresentation of major events in the listed companies. In the Provisions of the Trial of Supreme People's Court on Civil Compensation Cases Caused by False Statement in the Securities Market, the false statement on the securities market is considered to be " a false, misleading statement violating the truth in the process of issuing or trading of securities ", and in the context of the next major event, it can be concluded that the term" significant events "includes the listing documents, interim reports, annual reports, and other events which will have significant impact towards transactions of listed companies . In this connection, it can be inferred that if the listed companies have financial statement fraud, and false financial information showing in the listing documents, interim reports and annual reports, it can be considered they make a false record of "significant Incident" contrary to the truth according to the judicial interpretation of the meaning.

In the case of the court, the definition of "significant event" is not the same as the one defined above according to its meaning. In the retrial verdict, the Supreme Court said, "whether the matter and the data on the financial accounting report constitute a major event, the comprehensive judgments should be made from the amount involved, the nature of the incident and the impact. " If the judicial interpretation that whether the financial statement fraud of the listed companies constitutes a false statement is based on the formal judgment standard, that is, whether the listed company conducts financial statement fraud in the interim report and the annual financial report, the Supreme Court shall adopt proper standard toward the false statement in the case of Huawen Media, for whether the financial statement fraud of listed companies involves a large amount of money, whether the nature of this event is bad, whether it has a greater impact on the securities trading market.

\footnotetext{
(4) See Zhu Minjuan v Huawen Media Investment Group Co., Ltd., the Supreme Court (2013) No. 1820, November 29, 2013.
} 
Although it is more reasonable and economical to judge whether the listed company should bear the liability for damages investors suffer, it has not set this substantive standard in securities legislation in China. The court in practice can only judge by virtue of the judge's subjective judgments to determine whether the financial statement fraud of listed companies achieve the standard of false statements in the "amount involved, the nature of the incident and impact it caused" and other aspects. Lacking in specific indicators to bear legal responsibility for the financial statement fraud of listed companies in the context of securities law is also one of the reasons the current judge often require the CSRC's decision as an important basis for administrative penalties in the making of securities misrepresentation of civil compensation cases. The further development of this phenomenon is related to the incompleteness of the legal system of financial supervision in China [7]. The characteristics that financial legislation lags behind the financial practice make the courts of the judicatory slightly weak, resulting in the over-reliance of courts on administrative regulation in the identification, as well as the lack of confidence in independent judgments. And this situation reflecting in the investors who suffer from the financial statement fraud of listed companies in the stock market is the increase of litigation costs, as well as the pessimistic expectations of the outcome of the litigation, affecting their enthusiasm to protect their own interests through litigation.

\section{The Lack of Main Body and the Disproportion of Proportionality in Legal Responsibility}

As far as China's current law and existing cases are concerned, when the financial statement fraud of listed companies is considered to be false statement and administrative penalty by the CSRC, the administrative responsibility is the listed company, the chairman of the listed company, the general manager, Chief financial officer and other responsible persons, directly responsible persons and the controlling shareholder and the actual controller. In the financial statement fraud of listed companies, should the person who assumes the responsibility of misrepresentation be confined to the above subjects?

Defining the scope of the main body of administrative responsibility, we should first clarify the administrative responsibility corresponding to the illegal acts. The definition of this illegal behavior in securities law is that it does not disclose the information in accordance with the regulations, or the record of disclosed information is false, but this definition can only summarize the disclosure of corporate accounting report, which is equivalent to the performance of financial statement fraud, not to include the behavior of financial statement fraud in the event occurred or having not yet succeeded occurring. The listed company executives, direct responsible persons are included in process of financial statement fraud of listed companies, including two acts-the preparation of the financial statements inconsistent with the facts and certified public accountants issued report with a major misleading possibility. The securities law provides the corresponding administrative responsibility to the person in charge of the listed company, the person directly responsible as well as the certified public accountant firm, but other relevant personnel who may cause CPA audit errors like the supplier, customer, shareholders, lawyers, independent experts and related party of the listed company that may provide the false information to the auditor during the negotiation with the auditor are free from the regulatory perspective .

The slight financial statement fraud of listed companies may not be subject to investigation and punishment by the Securities Commission after being subject to the administrative penalties imposed by the accounting department under the Accounting Act since a slight degree of financial statement fraud may not show in the company's report documents or the quality of its financial reporting documents will not get a greater impact even reflected. For the norms of financial behavior of listed companies from "Securities Law", it is reflected in the event often in a larger amount and the impact of more severe financial statement fraud. But even the impact of financial statement fraud is very bad, compared with the penalties for financial statement fraud the state power laid on the listed companies; significant benefits it obtained appear greater. Article 193 of the Securities Law stipulates that the amount of administrative penalty for listed companies is only 300,000 yuan to 600,000 yuan and the amount of punishment for individuals is 30,000 yuan to 300,000 yuan. Compared with the amount of illegal operation of the listed companies and the huge benefits responsible personnel seizing, it presents a very low illegal costs in the securities capital market. In China's securities market, the imbalance proportion caused by the too low illegal costs with too large profits is extremely detrimental to play the role of "securities law" in standardizing the system and punishing illegal trading behavior.

\section{OptimizATION OF SECURITIES CIVIL AND ADMINISTRATIVE LEGAL RESPONSIBILITY}

In general, it is difficult for market investors to find out the occurrence of securities violations, especially only from the financial accounting reports of listed companies that record significant misleading information since it is difficult for investors who lack in professional accounting and audit knowledge to find finance fraudulent behavior of listed companies. After the disclosure of the financial statement fraud, it takes long time for investors to sue the listed companies for civil compensation through the use of judicial remedies. It is necessary to review the accountability of system for financial statement fraud of listed companies while reconstructing the internal inefficiency and irrationality of the listed companies in order to effectively protect the rights and interests of the securities market investors.

This paper analyzes the law enforcement model of China's securities market by using the basic concepts of new comparative economics. There are two approaches of "private law enforcement" and "administrative supervision" in the accountability system of financial statement fraud of listed companies [8]. In the field of private law enforcement led by passive judicial power, investors who suffer from financial statement fraud of listed companies in the securities market can make use of the judicial judgment of the court to make up for their losses. The model of administrative supervision perform the right of law enforcement in the securities regulatory authority of China, which give the right to impose 
administrative penalties to the relevant responsible personnel after the incident of financial statement fraud in the listed companies. We should achieve a balance between private law enforcement and administrative supervision through system design to improve the accountability system of financial statement fraud in China's listed companies. On the one hand, it provides investors with an effective judicial relief path, and on the other hand, it will make listed companies realize the corresponding costs of illegal acts while obtain profits from financial statement fraud so as to play a deterrent role in the possible illegal acts in the future.

\section{A. Introducing Public Interest Litigation System in the Case of Civil Tort Dispute}

The discussion on the judicial way to provide more efficient and effective means for the investors in securities market can not only be applied to the after-sale relief of financial statement fraud of listed companies, but also can be widely applied to other types of securities civil liability disputes. The litigation of indefinite number in the relevant legal system of China is one of the litigation choices for the securities investment group in the past, but the application effect of this system on the civil disputes of securities has been criticized for a long time by the academic circles. In order to avoid the occurrence of "rational indifference" the phenomenon in the process of mass incidents and prevent the investors who take the initiative to seek judicial relief from being victims of "free riders" in the existing system framework of China's civil procedural law, We can consider the introduction of public interest litigation system in the field of securities infringement. For example, "Securities Investor and Futures Trader Protection Law" in Taiwan clearly mandate the protection institutions of investors interests can represent the securities investors for arbitration or prosecution on the incidents which cause damage to the majority of securities investors .

The advantages of this system are that the specialized investor protection institution is more professional in the litigation than the individual investor or the investor group, and share a variety of cumbersome procedures in part for the investor who suffers the damage in the process of securities infringement litigation. By reducing the burden of their rights, it can encourage more investors who suffer loss against to seek relief through judicial means. However, the definition of the nature of such a public interest litigation still needs for further exploration: the securities regulatory authorities to carry out litigation, or the establishment of an investor rights protection agencies; if we set up investor rights protection agencies, the nature of the general enterprise should be legal person, or the legal entity or social organization with non-profit nature. Therefore, the establishment of the public interest litigation system in the field of civil dispute of securities infringement needs to be put forward together with relevant supporting system.

\section{B. Expand the Scope of Responsible Body in Administrative Punishment}

As to the scope of responsible body of the administrative punishment of financial statement fraud and its limitations we has discussed as above, we can refer to the relevant statements in the Final Rule that the SEC made for the Sarbanes-Oxley Act for further analysis.

Under the background that there has exposed a number of financial statement fraud scandals of listed companies in the United States, introducing the Sox Act is considered as the most severe bill in the history of financial regulatory legislation in the United States. Section 303 of the Act made a note in the provision that the responsible, directors or associates of a listed company may impose influencing, compelling, manipulating or misleading in an independent certified public accountant who is auditing the financial statements of the company, causing misleading accounting statement. In the subsequent legislative work, the SEC also extended the scope of the responsible personnel in the financial statement fraud of listed companies according to the willingness of the article, not only including the management personnel of listed companies, but also" the related personnel ".In the definition of "associates", the SEC provides examples of such affiliates including creditors, clients, lawyers, legal financial consultants or specialist of listed companies with whom the CPA conducts liaison investigations on the authenticity of the audit during the auditing of the financial statements of the listed companies. Although the expansion of the list of administrative responsibility is also subject to some controversy, such as some of the letters to the SEC said that it may result in "Chilling effect" in the auditor communication process, and will affect the audit work of CPA. However, the SEC still believes that the expansion of the scope of legal liability in the process of generating false financial information disclosure that may cause major misunderstandings by investors in the securities market is conducive to giving full play to the deterrent effect of securities laws and regulations so as to regulate financial auditing behavior, improve the quality of disclosure of financial and accounting information and protect the interests of investors. (5)

In China's relevant accounting law, although the provisions stipulate that the CPA can investigate the relevant units and individuals to obtain evidence in the audit process, there is almost no illegal cost to conceal the true financial situation of listed companies, to induce the CPA providing a audit report with significant misunderstanding possibilities. We can set the administrative responsibility to some extent to ensure the efficiency and quality of the auditing work of listed companies by the certified public accountants such as administrative warning and fines.

\section{Adjust the Amount of Administrative Penalty}

There are two ways to calculate the amount of administrative penalties in China's Securities Law: proportional system and fixed amplitude system. For example, in the Article 188 and 189 of Securities Law stipulate that without approval, those who raise funds in a unauthorized public or disguised public way or those who issue securities approval fraudulently in public in illegal way will be fined of not less than 1 percent but not more than 5 percent. In the provision of liability for misrepresentation, the amount of fines within the fixed range is

\footnotetext{
(5) U.S. Securities and Exchange Commission, Final Rule: Improper Influence on Conduct of Audits, http://www.sec.gov/rules/final/3447890.htm\#footnote_33, Nov. 27, 2016 last visit.
} 
directly set for the company and the responsible person. ${ }^{(6)}$ The punishment of proportionality system has its flexibility, cushioning the economic development, inflation and other factors on the impact of the amount of administrative fines. The reason why the proportionality calculation is not used in the administrative penalty of the false statement may be related to the fact that the damage caused by the false statements or the calculation of the interests of the listed companies in this behavior cannot be accurately quantified.

But there is no adjustment to punish the behavior of financial statement fraud of the listed companies in the securities law, that is, article 193 of Securities Law has not been changed since the introduction of Securities Law in 1998. And this amount of money, which spans two centuries and still maintains the original provisions of the liability clauses, cannot satisfy the administrative penalty of "increasing the cost of illegality, deterring violations and preventing the perpetrator from benefiting from the wrongful act" [9]. Combined with the questions on the "too slight punishment", the adjustments to improve the maximization of punishment should also be one of the factors for restructuring the responsibility system of financial statement fraud in the listed companies according to the principle of "equivalent penalty". ${ }^{7}$

\section{CONCLUSION}

In view of the financial statement fraud phenomenon of the listed companies in the securities market, this article first makes a reflection on the validity of the existing legal liability in securities law. From the litigation rights of securities investors and their practice of the status quo, we found that there is a conflict between the judicial interpretation and case practice, that the missing of responsible body and proportional imbalance set by the legal responsibility are the core causes of the relevant invalid legal responsibility. Accordingly, this paper puts forward three measures: firstly, introducing public interest litigation system in securities tort dispute cases; secondly, expanding the scope of the responsible body of administrative punishment; thirdly, strengthening administrative penalty and raise the cost of illegal. Finally standardize the order of China's securities market by improving the legal liability system of financial statement fraud of listed companies.

\section{REFERENCES}

[1] L. Li, S. Liu, and S. Jiang, "Listed companies' new trends and audit countermeasures on financial statement fraud," in Accounting Study, vol. 9, 2013, pp. 42-44.

\footnotetext{
(6) Article 193 of the Securities Law of the People's Republic of China stipulates: an issuer, a listed company or any other information disclosure responsible person fails to disclose information in accordance with the provisions, or the information disclosed has any false record, misleading statement or material omission, and shall be given a warning and a fine of not less than 300,000 yuan but not more than 600,000 yuan, shall be imposed on the person directly in charge and other directly responsible persons and a fine of not less than 30,000 yuan but not more than 300,000 yuan shall be imposed ${ }^{(7)}$ Article 4 of the Administrative Punishment Law of People's Republic of China stipulates: the administrative penalties shall be based on facts, and shall be commensurate with the facts, nature, circumstances and social harm of the illegal acts.
}

[2] Y. Liu, "from financial statement fraud to accounting disputes - a new vision on the regulation of china's securities market in the field of listed companies' Financial Information," in Securities Law Court, vol. 7, 2012, pp. 135-167.

[3] Z. Rezaee, "Causes, consequences, and deterrence of financial statement fraud," in Critical Perspectives on Accounting, vol. 16, 2005, pp. 277 298.

[4] T. Isa, "Impacts and losses caused by the fraudulent and manipulated financial information on economic decisions," in Review of International Comparative Management, vol. 12, 2011, pp. 929-939.

[5] Y. Zhou, B. Lan, "Reconstruction and optimization of securities administrative responsibility," in Tsinghua Law Review, vol. 3, 2010, pp 61-74.

[6] B. Black, "Should the SEC be a collection agency for defrauded investors," in The Business Lawyer, vol. 2, 2008, pp. 317-346.

[7] C. Xu, "Law, law enforcement and financial supervision - introduction of 'incomplete law' theory," in Economic and Social System Comparison, VOL. 5, 2001, PP. 1-12.

[8] S. Djankov, E. Glaeser, R. L. Porta, F. L. Silanes, A. Shieifer, "The new comparative economic," in Journal of Comparative Economics, vol. 4, 2003, pp. 595-619.

[9] B. Black, "Should the SEC be a collection agency for defrauded investors?," in The Business Lawyer, 2008, pp. 317-346. 